\title{
A tale of the new and the old: renovation of Yong'an Warehouse at Yangpu waterfront, Shanghai
}

\author{
Philip F. Yuan ${ }^{1 *}$, Xiaoyu $\mathrm{Wei}^{2}$ and Wei Yu ${ }^{3}$
}

\begin{abstract}
The urban riverside space of Shanghai is transforming. How to renovate industrial heritage buildings to renew their vitality while retaining their historical memories and integrate them into the contemporary cityscape and today's urban lifestyle is a common challenge encountered by contemporary architects. This article takes the renovation of Yong'an Warehouse as an example to showcase a typical heritage conservation project's design process. The architects took different approaches to accommodate the different statuses of the twin buildings of the Yong'an Warehouse, seeking to create a symbiotic twin relationship between the past and the present. This project adopted a conservation and utilisation approach that involves multilateral participation, emphasising value-oriented mythology, and providing an alternative thread for the renovation of historical architecture.
\end{abstract}

Keywords: Yong'an Warehouse, Heritage conservation, Historic architecture, Symbiotic twin, Renovation, Heritage value

Changes to urban infrastructure and urban functions and improvements in spatial quality continue to redefine massive urban industrial areas. Considered an essential part of Shanghai's urban development, the industrial architecture reflects not only typological characteristics but also the progression of contemporary industrialisation in China. As shown in Shanghai Cultural Development's Annual Report of 2018, the research on and renovation of industrial heritages has made significant progress since the first few representatives of modern architectural projects were announced in 1989. However, because of the limited reach and slow process of conservation, valid solutions are still needed to better renovate the city's heritage (Rong 2018, 128-144).

As urban development along the Huangpu River progressed in 2015, the Yangpu government approved the purchase of Yong'an Warehouse, which was included on a

\footnotetext{
* Correspondence: philipyuan007@tongji.edu.cn

${ }^{1}$ College of Architecture and Urban Planning, Tongji University, 1239 Siping Road, Shanghai 200092, China

Full list of author information is available at the end of the article
}

regulatory plan and conservation list devised by Professor Qing Chang and his team. The twin warehouses reentered the public consciousness after a century of trials and hardship (Fig. 1). As the urban development of the Yangpu waterfront proceeded, the potential transformation way of Yong'an Warehouse awaited exploration. To conserve and renovate such a heritage structure, the architect would need adequate historical background knowledge and be able to reinterpret Shanghai's urbanisation by communicating the specific fulfilments from groups of historical experts and local governors (Figs. 2 and 3).

\section{History of Yong'an Warehouse}

Yong'an (also known as Wing On) Warehouse is located in the old Yangpu industrial district along the banks of the Huangpu River. It was originally a storage facility for the first factory of the Wing On Textile Co., Ltd. The company was established in 1922 by Chinese Australian merchants Kwok Lok and Kwok Sun. The two brothers helped to revolutionise traditional Chinese business practices by importing modern management techniques

\section{Springer Open}

(c) The Author(s). 2021 Open Access This article is licensed under a Creative Commons Attribution 4.0 International License, which permits use, sharing, adaptation, distribution and reproduction in any medium or format, as long as you give appropriate credit to the original author(s) and the source, provide a link to the Creative Commons licence, and indicate if changes were made. The images or other third party material in this article are included in the article's Creative Commons licence, unless indicated otherwise in a credit line to the material. If material is not included in the article's Creative Commons licence and your intended use is not permitted by statutory regulation or exceeds the permitted use, you will need to obtain permission directly from the copyright holder. To view a copy of this licence, visit http://creativecommons.org/licenses/by/4.0/. 


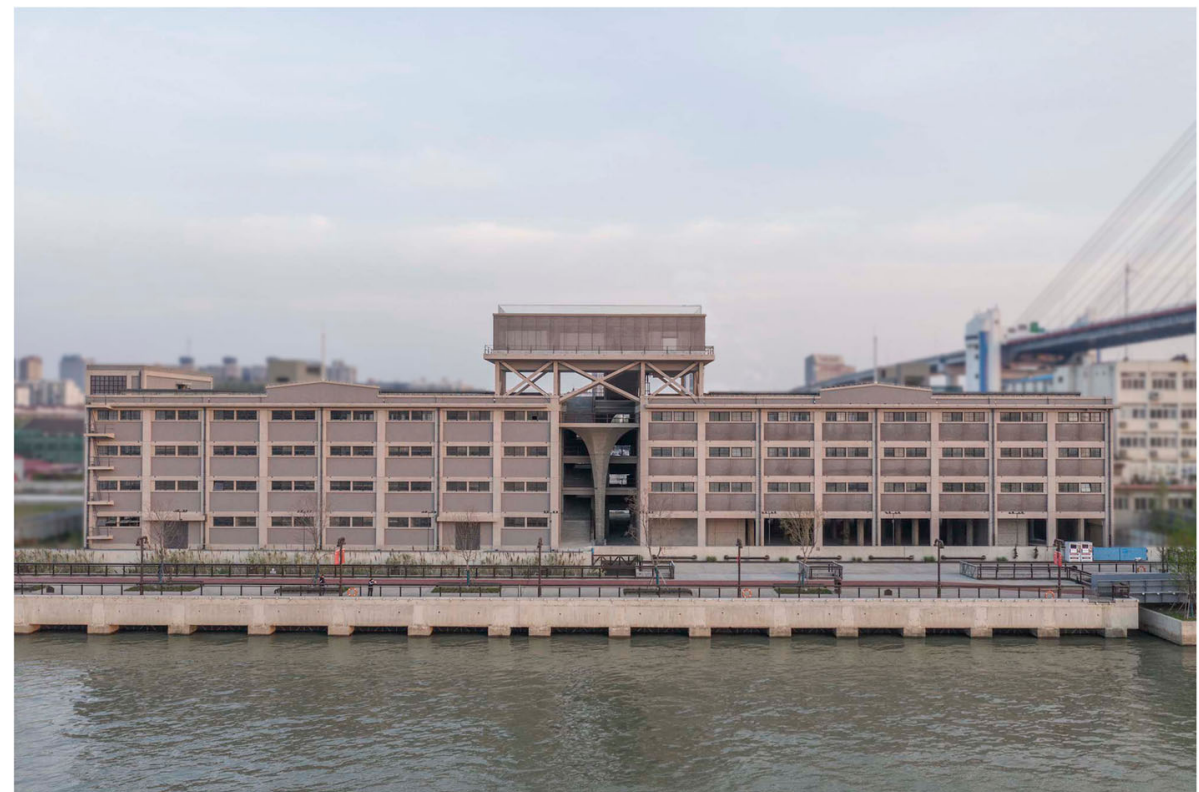

Fig. 1 View from the Yangpu waterfront: Yong'an Warehouse (Source: Fangfang Tian)

and opening Shanghai's famous Wing On Department Store on Nanjing Road. The Yong'an Textile Company was part of the company's interlocking organisation that transformed Shanghai's economy and made it into a cotton textile powerhouse. It was among the most important Chinese firms in the 20th century. Designed and built in 1922, the Yong'an Warehouse was second only to that of the Shenxin Textile Company. As it grew in scale and management efficiency, the Yong'an Textile Company established five factories and a mill, which absorbed the first factory to become Yong'an Textile Mill. Thousands of cotton goods were manufactured and stored in the facility each day. The Yong'an Warehouse was occupied by the Japanese in 1937 and then was taken over by Shanghai No. 29 Cotton Mill after 1949. In 1961, part of the building was assigned to the

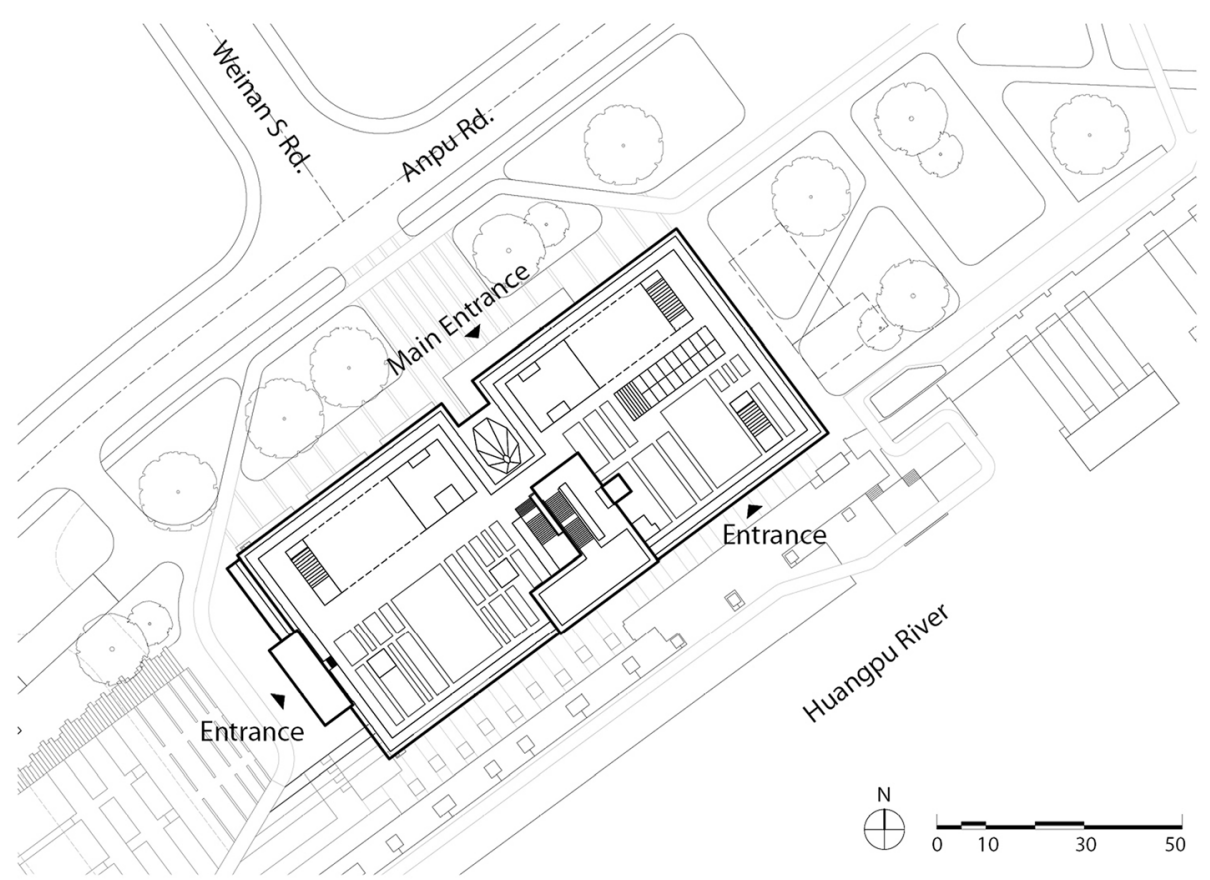

Fig. 2 Yong'an Warehouse Masterplan (Source: Archi-Union Architects) 


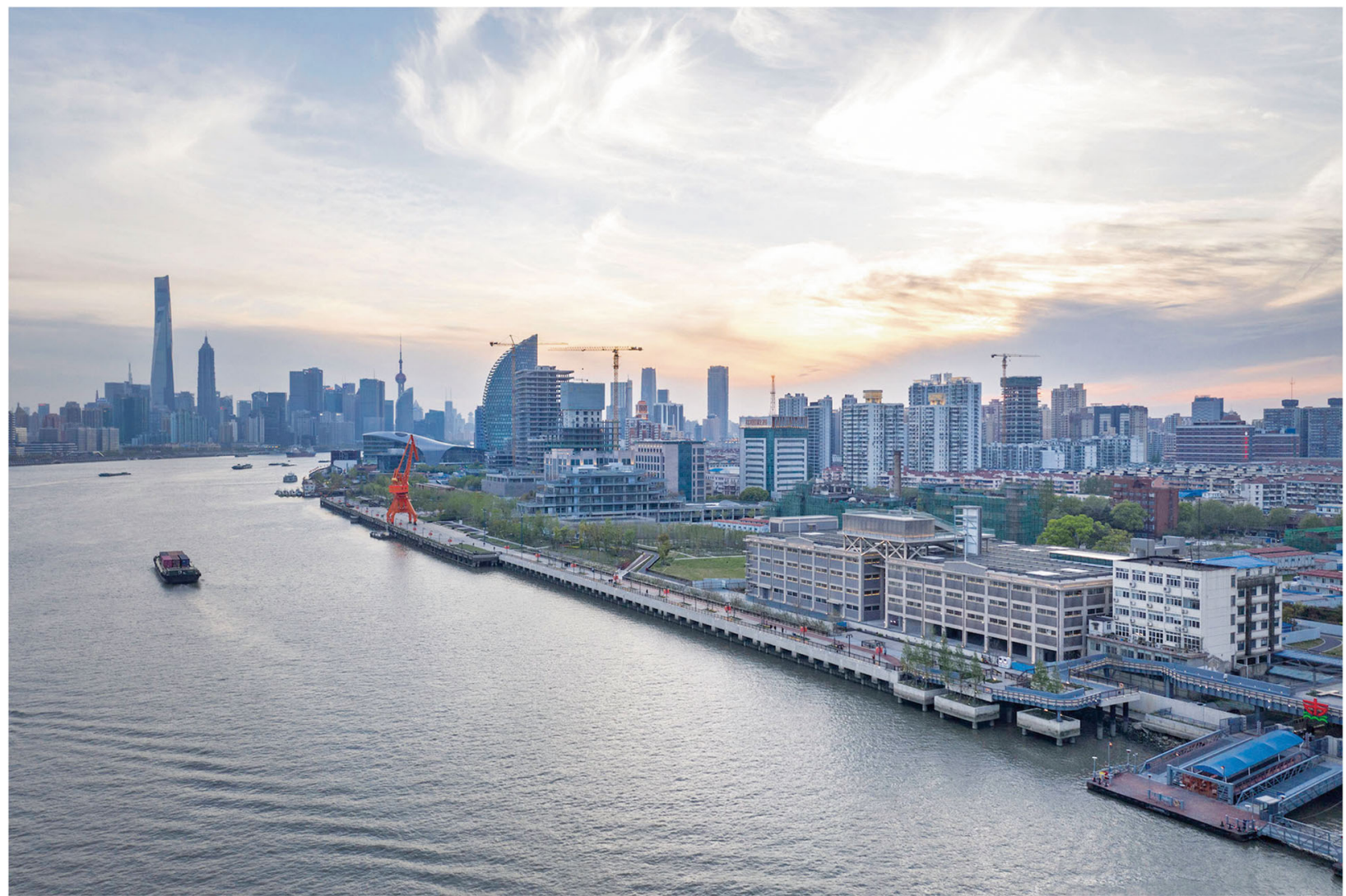

Fig. 3 An overview of the Yangpu waterfront and Yong'an Warehouse (Source: Fangfang Tian)

Shanghai Chemical Plant, which used it to store raw material. The building gradually fell into decay. It is currently the only facility of its kind remaining and a rare example of Shanghai's industrial heritage.

The warehouse consists of two 4-storey buildings opposing each other on a north-south axis facing the Huangpu waterfront. They were built in an eclectic modern style with simple, clean lines. Each squareshaped floor is $2400 \mathrm{~m}^{2}$, for a total of $20,000 \mathrm{~m}^{2}$ (Fig. 4). According to historical records and photos, the warehouse was built with a reinforced concrete frame structure and a well-preserved façade. A beamless superstructure system, octagonal prismatic columns and angled bucket caps brought out the unique characteristics of the interiors. (Fig. 5).

Frequent takeovers and two consecutive wars resulted in substantial damage to the warehouse's structure. In the 1990s, due to the development of the market economy and land exchange, the east building was converted into the storage unit in Shanghai's New Organic Material Industrial Complex and later into an office building in the Yangpu Jingyuan Cultural Creative Garden. To allow the building to fulfil its new functions, several columns were removed and replaced by a staircase, the interior space was covered in white paint, and most of the exterior walls were demolished and replaced with glass windows during the renovation process. These changes caused irreversible damage to the original appearance of the historic warehouse. However, they offered new opportunities for the rebirth of Yong'an Warehouse during the urban development of the Yangpu Waterfront.

\section{Research and renovation strategies}

At the beginning of the project, the design team of Archi-Union Architects explored different methods of investigation and preparation.

First, the warehouse's structures were in poor condition, with the structural components, interior and exterior walls, apertures and steel frames showing different degrees of damage. Traces of graffiti and several repaints were visible in the warehouse. After a number of functional transformations, the east wing building's elevation and interior space bore no resemblance to the original. A new room had been added on the west side in 1999 . Later, in 2011, the original water tank on the rooftop was removed. Each step taken was another heavy blow dealt with the warehouse's original appearance.

In addition, overloading during industrial production had resulted in fractures and deformations of the 


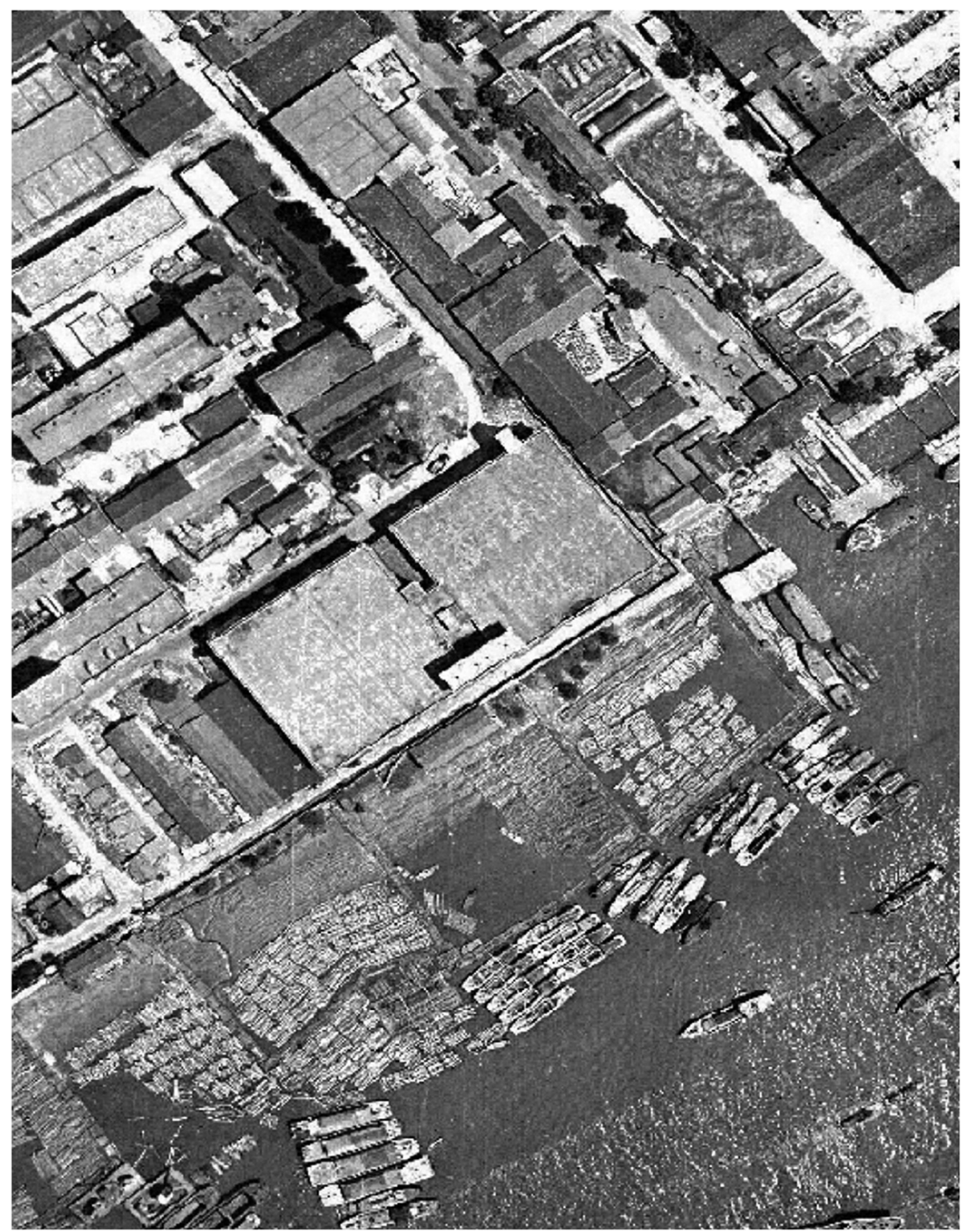

Fig. 4 Aerial view of the historical Yong'an Warehouse in 1979 (Source: https://www.shanghai-map.net/shtdt/multi-images/index.html)
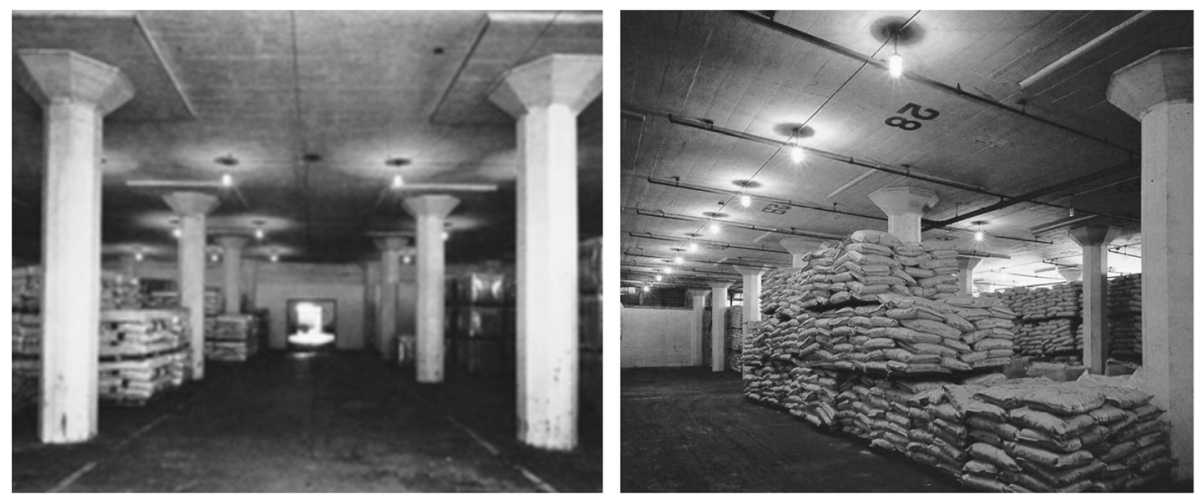

Fig. 5 Historical photos of Yong'an Warehouse (Source: Research on Spatial Characteristics of Industrial Heritages and Protection Strategies at Yangpu Waterfront, Professor Qing Chang's team, August 2016) 
columns. The evaluations indicated that the structural integrity was not sufficient for the warehouse to be used for commercial purposes. Additionally, the shear strength of the horizontal beams had to be reinforced to meet seismic code requirements. The interior walls were generally solid but blocked the view and natural light. Air circulation was impaired by the overwhelming depth of the interior space. The original entrance to the building was not distinguishable and could thus not be used for orientation. The lack of internal connection within the building made it impossible to satisfy the fire codes (Fig. 6). Additionally, the means for thermal insulation within the building were not sufficient to meet the sustainable building codes and standards.

According to the Venice Charter (1964) ${ }^{1}$, authenticity, integrity, minimal intervention and legibility are the basic principles of heritage conservation in practice. However, this set of criteria may require further evaluation once applied to the realities on the ground (ICOMOS 1964). Taking Yong'an Warehouse as an example, when its historical background is merged with its modern functions, three phases emerge: the original building, the destructive renovations and the rebirth. Therefore, integrating these three phases into a single life cycle became a turning point in the design of the project. The architect must understand the historical background of the original building and balance the tension between conservation and contemporary utilisation.

Early twentieth-century art historian Alois Riegl once discussed the value of commemoration in the past versus in the present. He pointed out the openness and diversity of value systems, leading people to rethink heritage conservation and consider the need to account for individual characteristics and context (Riegl 1982). Current value-oriented strategies and theories consider the actual value and protection methods as the priority rather than the object itself (Mason 2016). The ultimate goal has thus shifted from preserving reality to preserving meaning, replacing the pivot point of the authenticity of heritage with its cultural importance (Muñoz

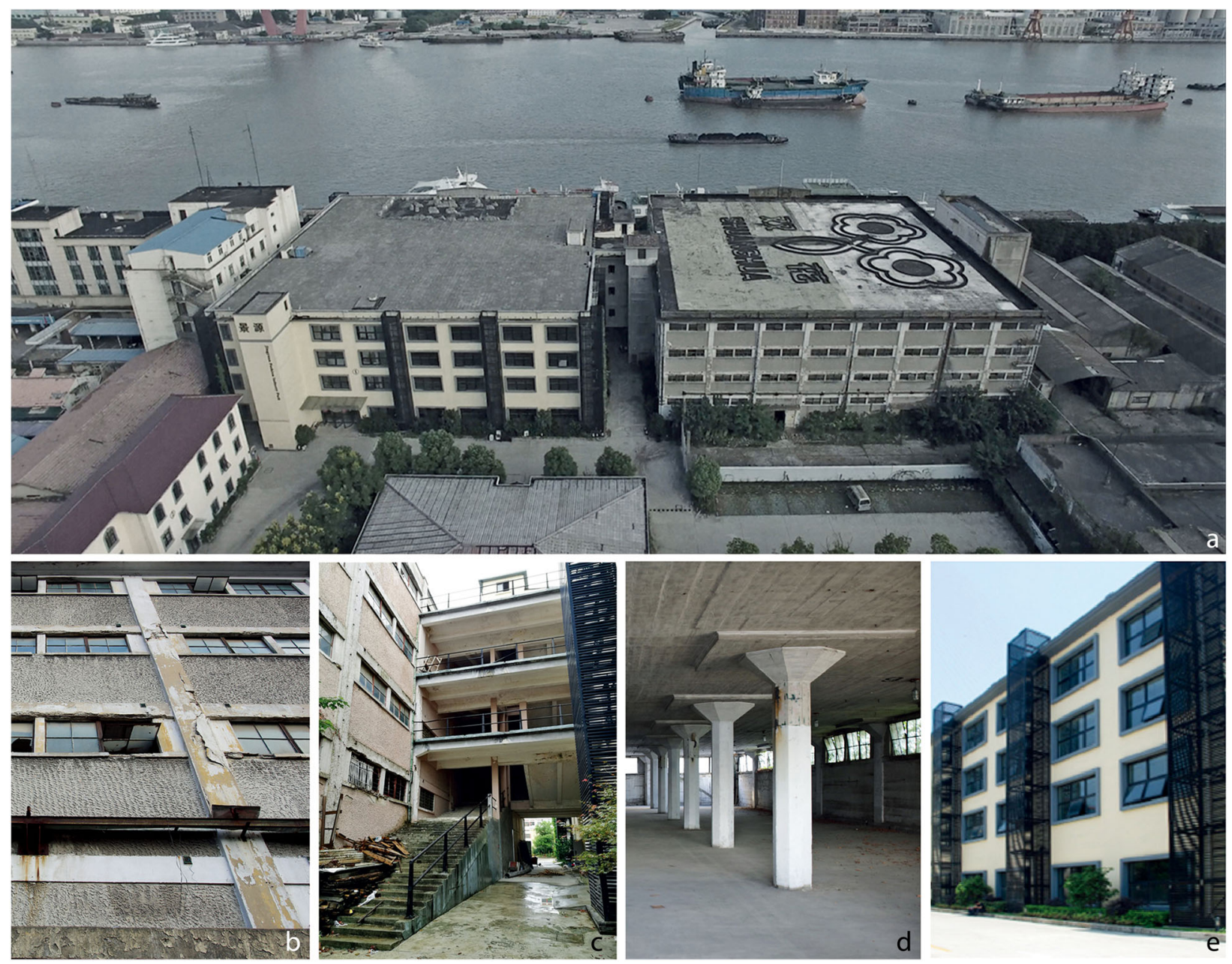

Fig. 6 Yong'an Warehouse before the renovation. a: aerial view of the site. b: destroyed exterior walls. c: the connection between the east and west wings. d: interior space. e: renovated eastern warehouse: office building (Source: Archi-Union Architects) 
Viñas 2012, 151-155, 177-180; Chen and Zhang 2018). This spurred new approaches among architects to historic preservation and renovation in complex contexts because of the need to plan a balanced strategy based on a thorough and comprehensive understanding of historic authenticity and cultural importance.

Yong'an Warehouse was listed among the permanent cultural heritage in Yangpu District because it witnessed the industrial development of China. Not only is the warehouse one of the only remaining examples of the traditional industrial facilities of 1920 s Shanghai, but also its beamless superstructure system was state-of-the-art in its time. Its artistic and scientific characteristics are thus invaluable to research. Further, the open site of the Yangpu waterfront has potential for space reuse and redevelopment. The value of the warehouse throughout its history needed to be balanced with its cultural value, although the previous renovation and existed damage was not seriously impacting the heritage conservation.

Based on the existing design problems and renovation goals, the architects specified the following design strategies:

(1) Preserving the existing façades, structural systems, and spatial composition to preserve the building's essential historical record and artistic features;

(2) Implementing new technologies to repair the destroyed components with the goal of reflecting the past and presenting the comprehensive history of the twin warehouses;

(3) Minimal intervening to ensure the building fulfils contemporary design standards and functional requirements.

\section{Technological intervention and renovation- redux of the original}

During the various phases of the design process, the architects adopted different methods to clean, repair and reinforce the building consistent with its spatial composition and functions. Based on heritage values, they determined which historical information had to be retained. Even though the materials for the renovation could not be the same as those used in the past, the architect asked that the craftsmanship be as close as possible to the original, therefore maximising the expression of artistic value. Eventually, the interior structures, as well as the western façade, were successfully preserved in a way that resembled the original.

\subsection{Reinforcing the beamless superstructure system}

Yong'an Warehouse represents one of the first implementations of a beamless superstructure system in China. The structural systems within the twin buildings were fully retained, but the interior walls had been repeatedly repainted. Thus, the design team used a highpressure water gun to clean the entire structure of the remaining paint and carefully restored the reinforced concrete frame structures to their original state.

The architects analysed the building structure and frequently met with the local Cultural Heritage Department to discuss the seismic requirements. They came up with a solution to insert eight reinforced concrete core tubes, strengthen the horizontal supports and provide for emergency evacuation routes and equipment installation without the removal of any of the octagonal prismatic columns (Fig. 7). To address the rooftop's loading standards, they decided to insert steel interlayers into the top floor and rooftop structures, which invisibly increased the load capacity for the equipment.

Furthermore, the reinforced steel panels and frames in the original building were retained, and reinforced concrete was applied for renovation. The change in materials also reflected the transformation of the building structure as well as its interior space (Figs. 8 and 9).

\subsection{Renovating the peripheral compartments}

Yong'an Warehouse was built in a modern style with a clear sense of architectural rhythm. The building's west wing most clearly retained the appearance of the original façade. After the outer layer of paint was removed, the stuccoed texture of the concrete was clear to the eye. As the structural integrity of the interior walls was largely compromised due to repeated damage, for safety reasons, the design team decided that $80 \%$ of the walls needed to be renovated. Because of the difficulty of preserving the traces of erosion while making the structure stable, the team decided to restore the walls to their original state.

The architects collaborated with a group of experts to experiment with and test the concrete stuccoed technique to replicate the original appearance of the exterior walls. They also invited craftsmen equipped with traditional skills to repair the old aperture compartments.

Balancing the new and the old through an understanding of their relationship, minimal intervention has always been the key to renovations of historic architecture. For Yong'an Warehouse, a design process following the symbiotic twin strategy was used for the east wing building, which had less preservation value, to honour its historical origin and maintain the project's underlying coherence. Overall, characteristics such as the building's footage and the general silhouette were generally retained since the design details could distinguish the new from the old. (Fig. 10). 

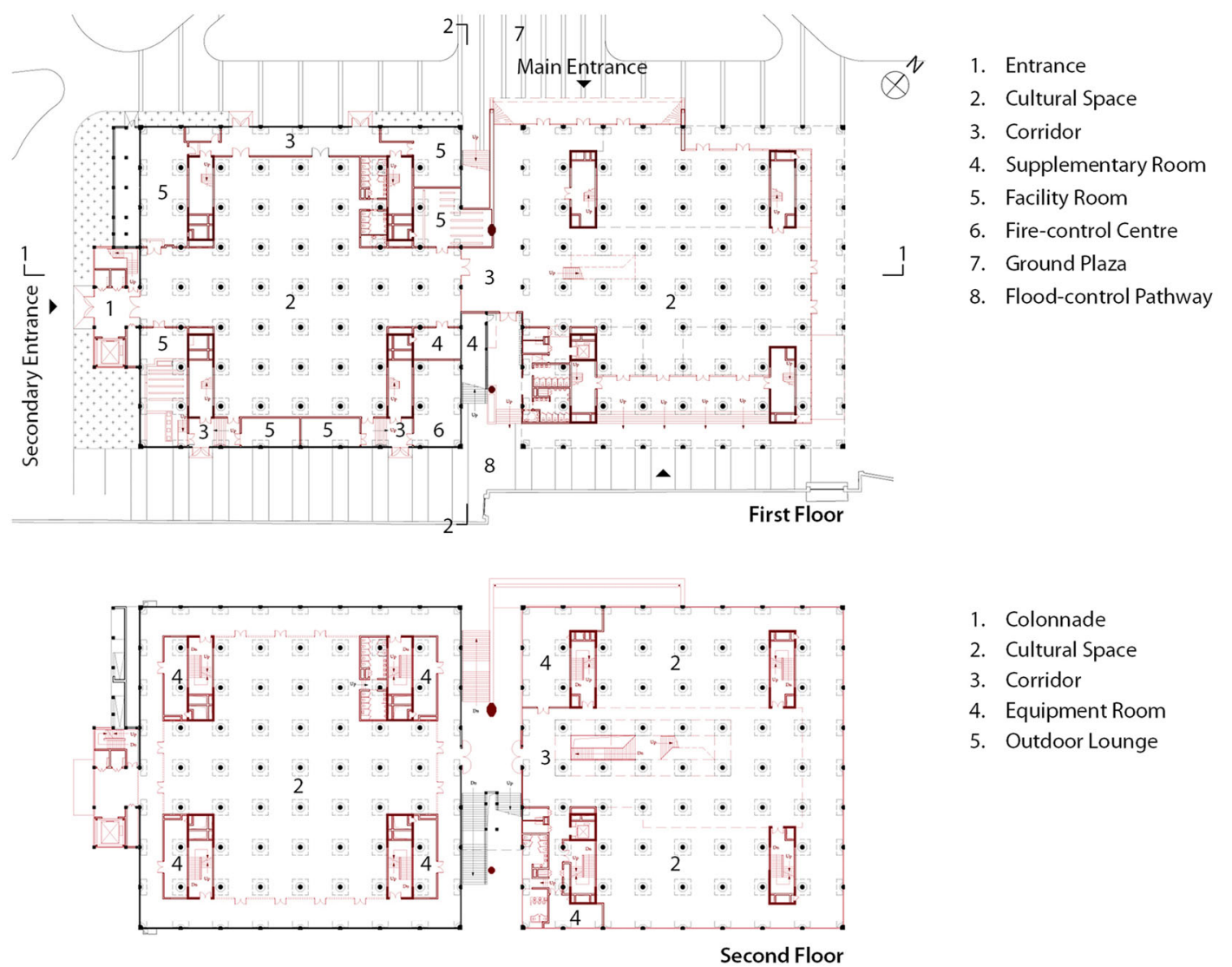

1. Colonnade

2. Cultural Space

3. Corridor

4. Equipment Room

5. Outdoor Lounge
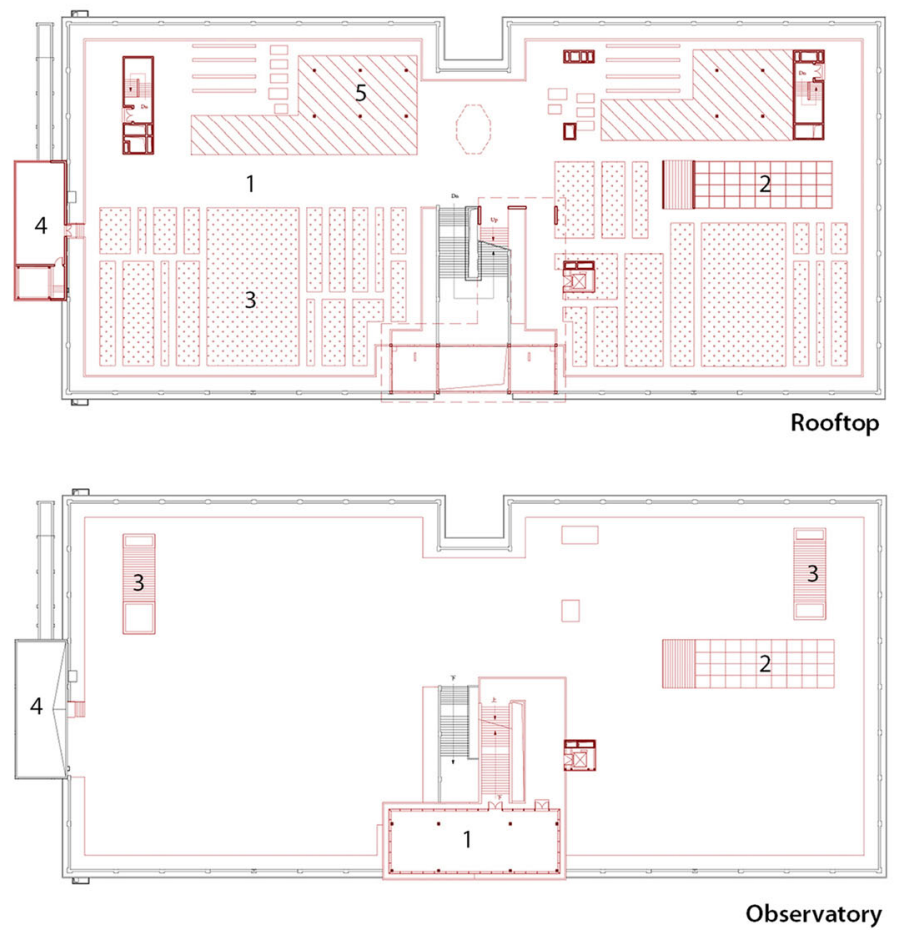

1. Rooftop Space

2. Atrium with glass ceiling

3. Rooftop Vegetation

4. Fire-control Water Tank

5. Solar Photovoltaic Room

1. Observatory

2. Atrium with glass ceiling

3. Ceiling system: Core-tubes

4. Solar Photovoltaic Room

Fig. 7 Plans of the Yong'an Warehouse renovation (Source: Archi-Union Architects) 


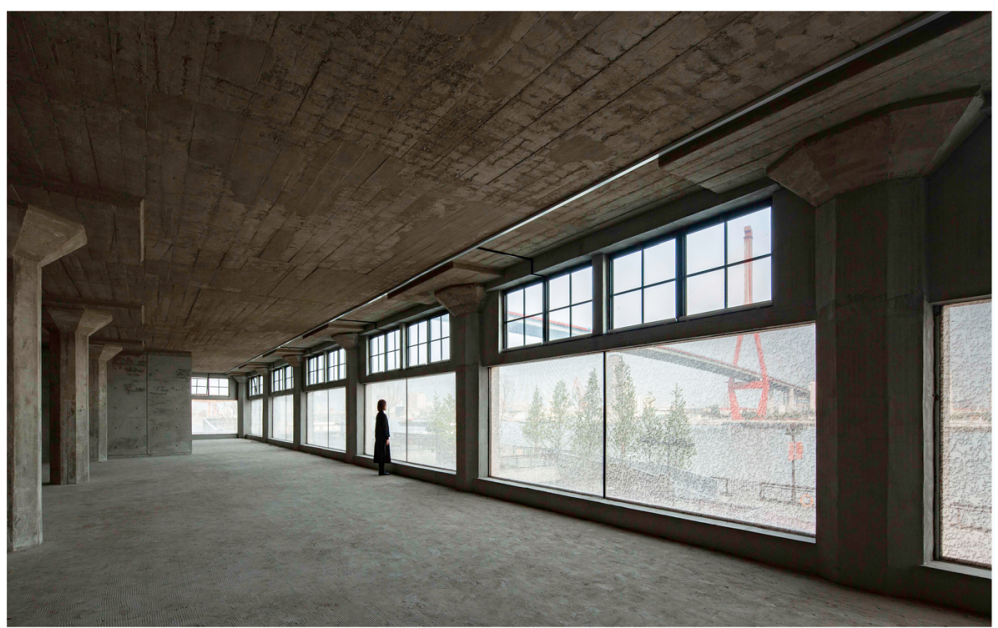

Fig. 8 Renovated beam and slab structures on the top level (Source: Tianzhou Yang)

\subsection{Renovating the twin Façades}

The fact that the east wing building had gone through several severe reconstructions enabled the architects to move beyond an exact replication and to instead apply novel technologies to revive the rhythm and imagery of the original façade. For instance, they used screen printing to reproduce the stuccoed texture on glass panels. The printed images were taken from the restored west building and transferred at an exact 1:1 ratio onto the glass panels (Figs. 11 and 12). After careful calibration, the panels, once installed, made the two buildings almost identical from a distance but distinctively different up close. In this way, the warehouse's three life phases, as represented by its historical façade, the marks of previous renovations and the new façade of screen-printed glass, were all shown in a single view. The high and low light of the twin buildings at night indicated the symbiotic twin relationship connecting the past and the future (Figs. 13 and 14).

To meet the green building standards, the screenprinted glass became part of a triple-layered glass window system with insulating air between the layers. Each opening is composed of two of these glass panels. Similar techniques were applied to the loading dock on the west side and to the façade of the side building. The loading dock was maintained in its original form. However, the side room built in 1990 was preserved only with its mainframe structure. The entrance was replaced with screen-printed glass panels as well.

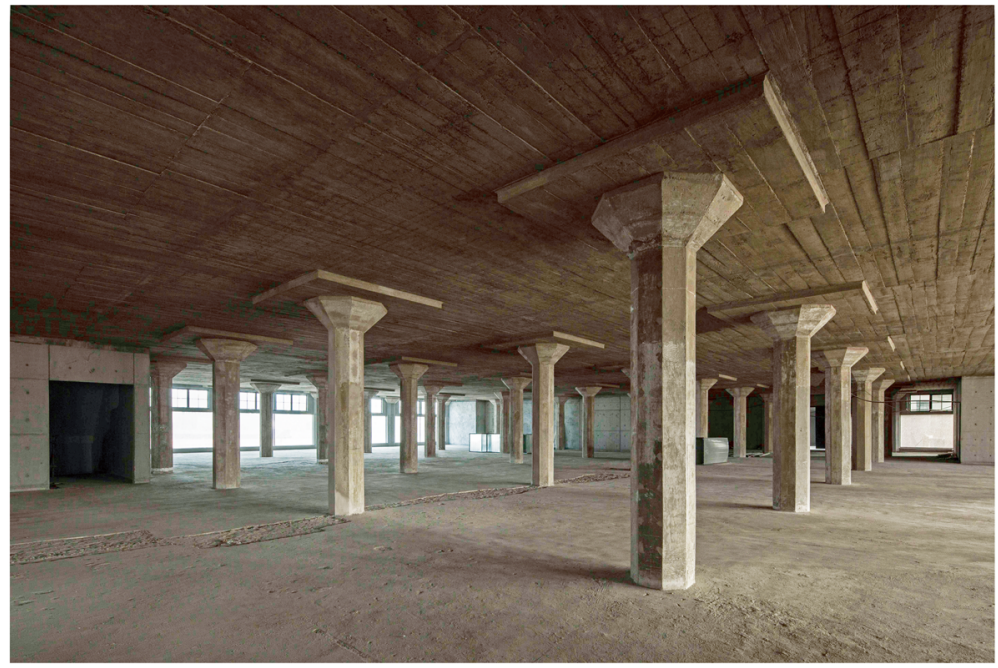

Fig. 9 Renovated beamless structural system of the interior (Source: Tianzhou Yang) 


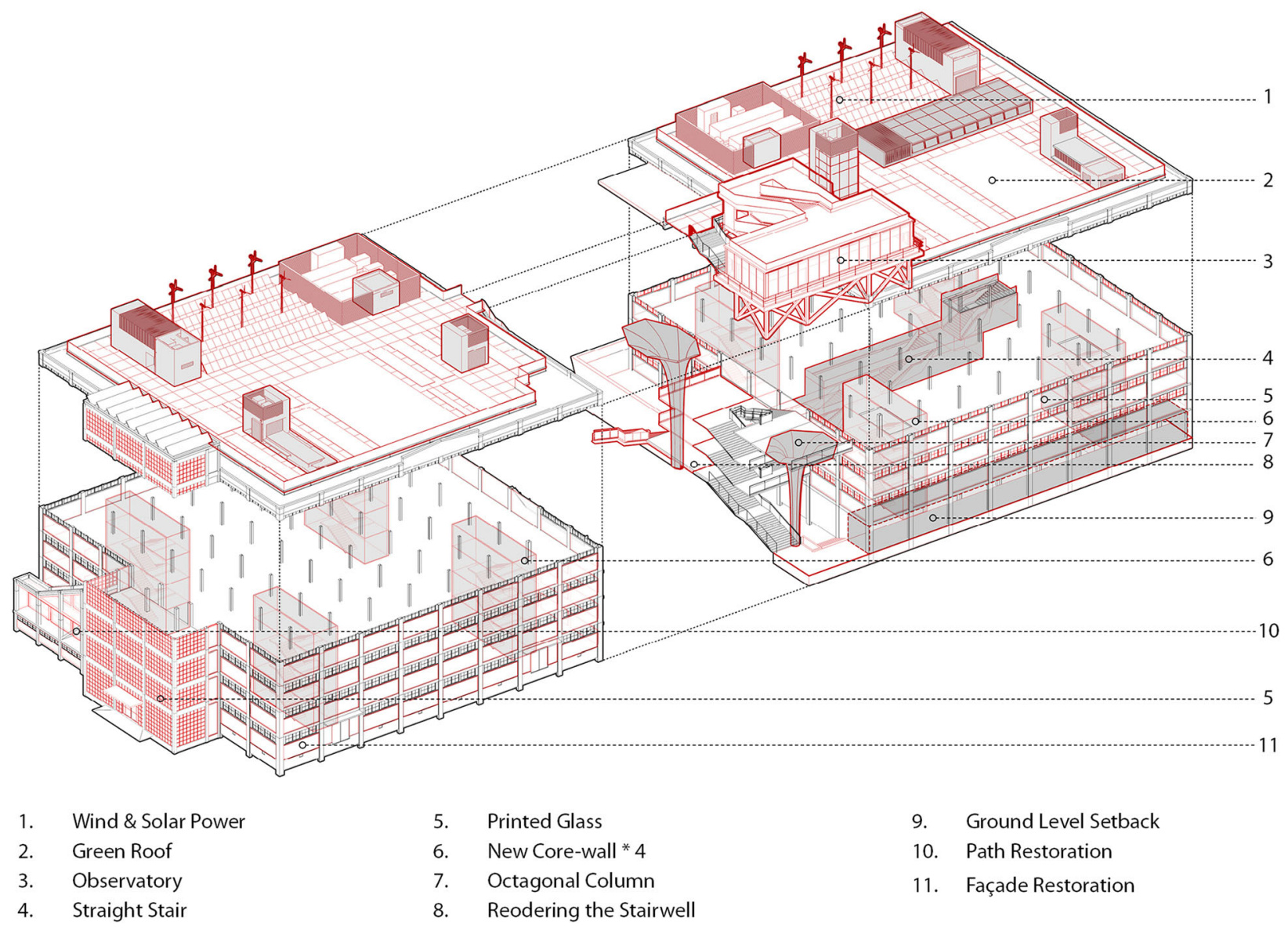

Fig. 10 Axonometric view of Yong'an Warehouse (Source: Archi-Union Architects)

\subsection{Rebuilding the historical water tank}

In 2011, the original water tank was removed, which separated the two building volumes and destroyed the unique quality of the industrial structure in terms of the overall composition. To recreate the rhythmic silhouette, the architects decided to reuse the original water tank as a formal guideline for an observatory on the rooftop with a complete steel structure instead of a steel and concrete structure. The new form corresponds with that of the historic water tank, uses screen-printed glass for the façades, and connects the two opposing building volumes with a public staircase. The upward sightseeing route provides grand views for visitors of the Yangpu waterfront (Figs. 7 and 15).

\subsection{Spatial reordering}

The architects reemphasised the entrance by using steel plates and modernist design language to direct the public path into the twin buildings. New gigantic columns and staircases were added, which expanded the square footage of the second floor, created new circulation and the observatory, and provided shade for the middle pathway. The gigantic columns took their forms from the original octagonal prismatic columns' deconstructed curves, which constituted the rainwater drainage systems. The exaggerated forms overturned the stereotypical static impression of the warehouses and corresponded to the internal structures, making the middle pathway the building's focal point. The new parts were built separately from the original structure to ensure the reversibility of the operation (Fig. 16).

Through an atrium and a public staircase in the east wing and the staggered arrangement of its sections, the additions were able to direct the natural light and make Yangpu Bridge's frame structure visible through the skylight, inviting visitors to ascend.

\subsection{Integrating into the urban environment}

The architects indented the exterior walls one column span inwards to expose the original first-floor columns on the south, east and north sides, creating a $6 \mathrm{~m}$ wide transitional lounge. This not only showcased the beauty of the historic architecture to the city but also facilitated 


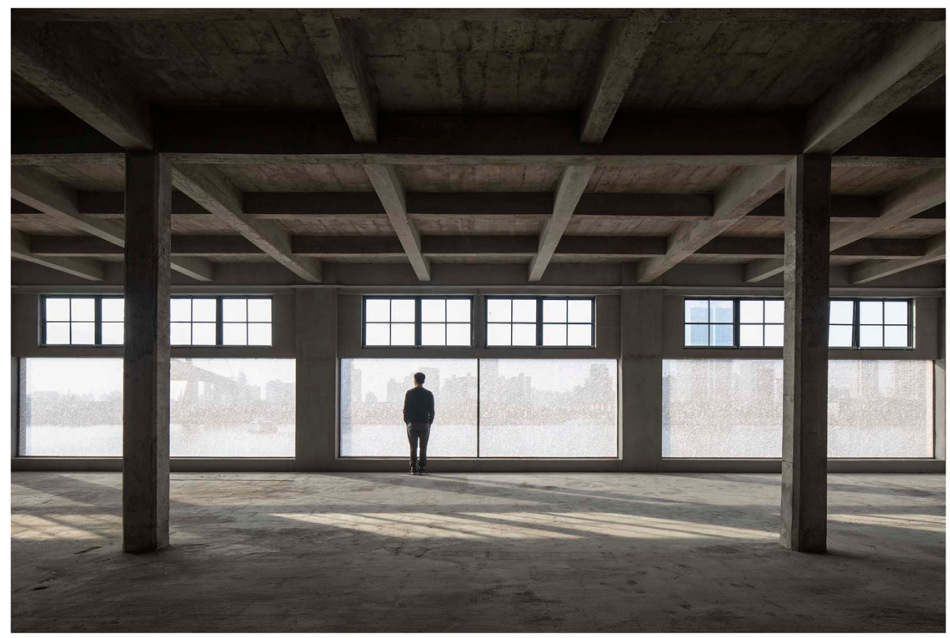

Fig. 11 Internal view of the façades made of screen-printed glass (Source: Fangfang Tian)
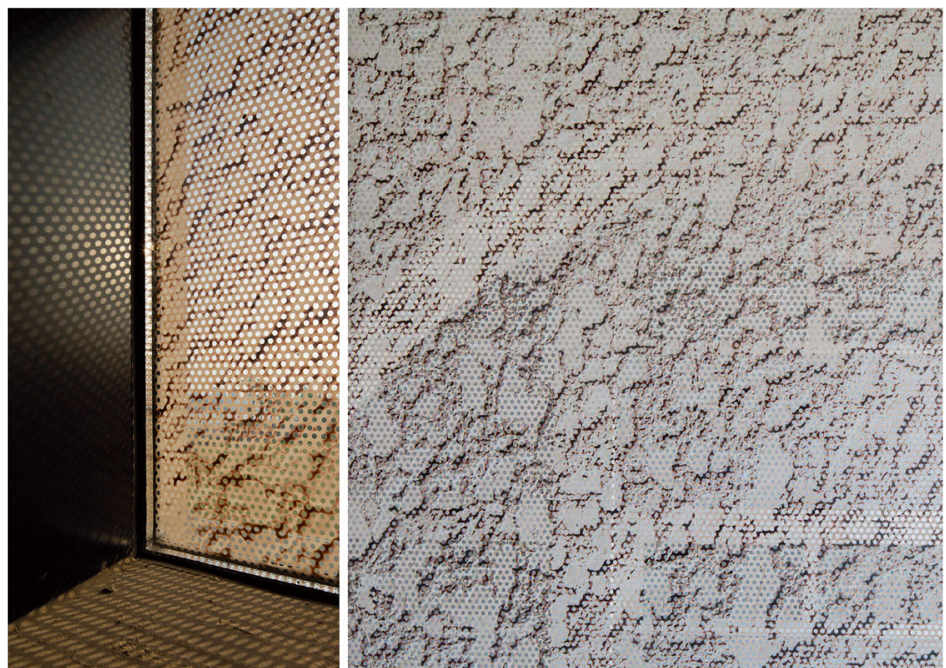

Fig. 12 Details of the screen-printed glass panels (Source: left by Tianzhou Yang; right by Fangfang Tian)

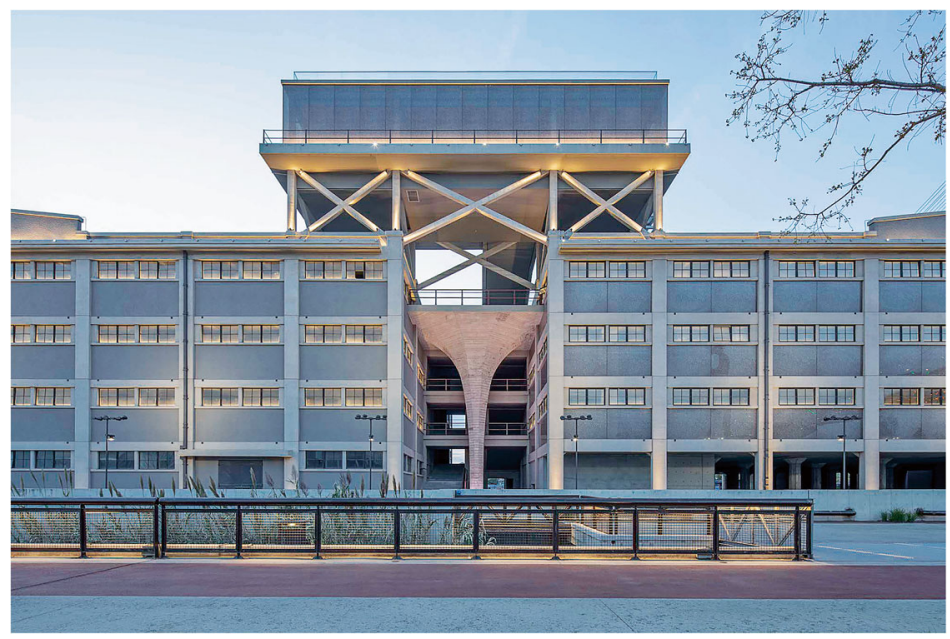

Fig. 13 Symbiotic Twin Façades: the old and the new (Source: Fangfang Tian) 


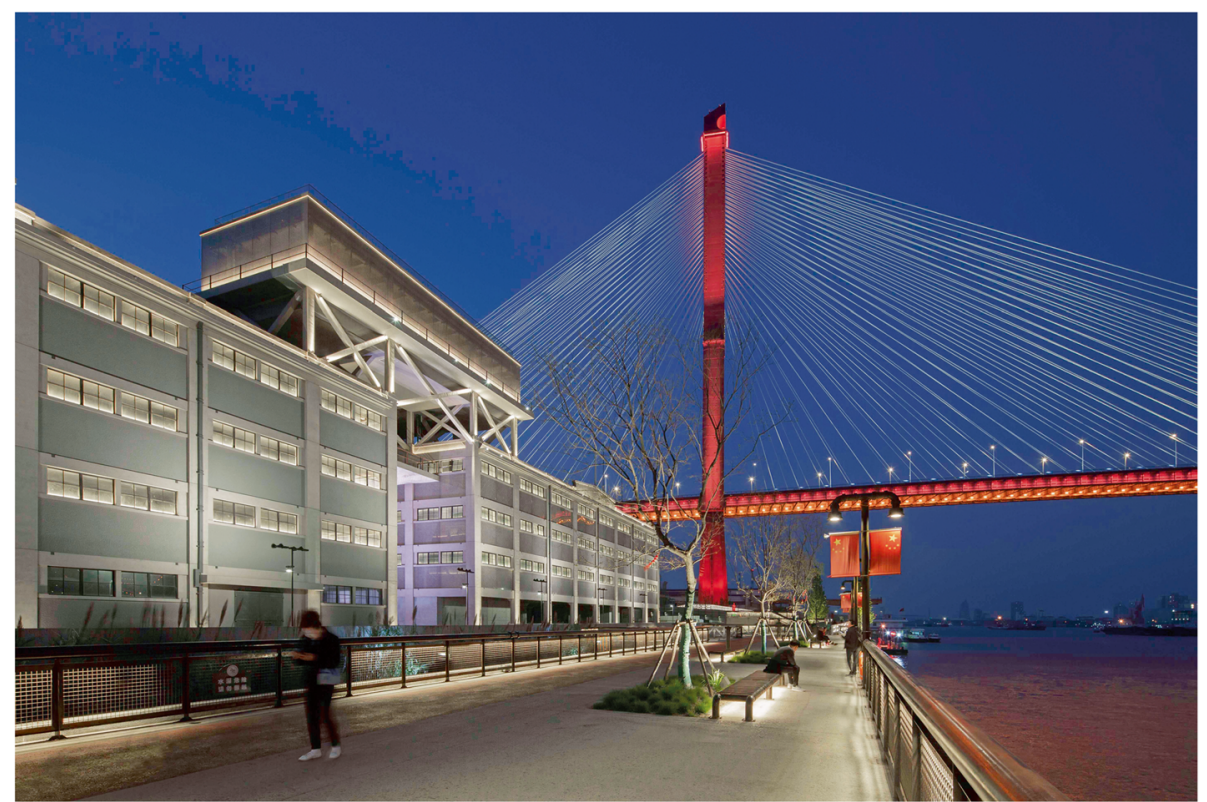

Fig. 14 Walking path along the river (Source: Tianzhou Yang)

a pedestrian passage. The design raised the interior floor level to match the existing flood-control walls, creating a linear spatial experience between the interior, the colonnade, and the riverside recreational spaces.

\section{Implementation of ecological technologies into historic architecture}

Yong'an Warehouse's architectural performance was already outdated by modern standards. To improve its effectiveness and extend the building's life cycle, the architects implemented 10 green ecological technologies following the principle of minimal intervention and in accordance with the building's spatial characteristics (Fig. 17).

In the original warehouse, there was no capacity for thermal storage even though the interior space was highly flexible. When reorganising the interior space, the architects turned the colonnade into a transitional space that adjusts the indoor and outdoor environment. This was done by regulating the interior environment through an architectural spatial strategy. The colonnade's natural ventilation during summer and heat emission during the winter can reduce the energy consumption by $30 \%$, providing a supplementary space for various events and activities. The phase-
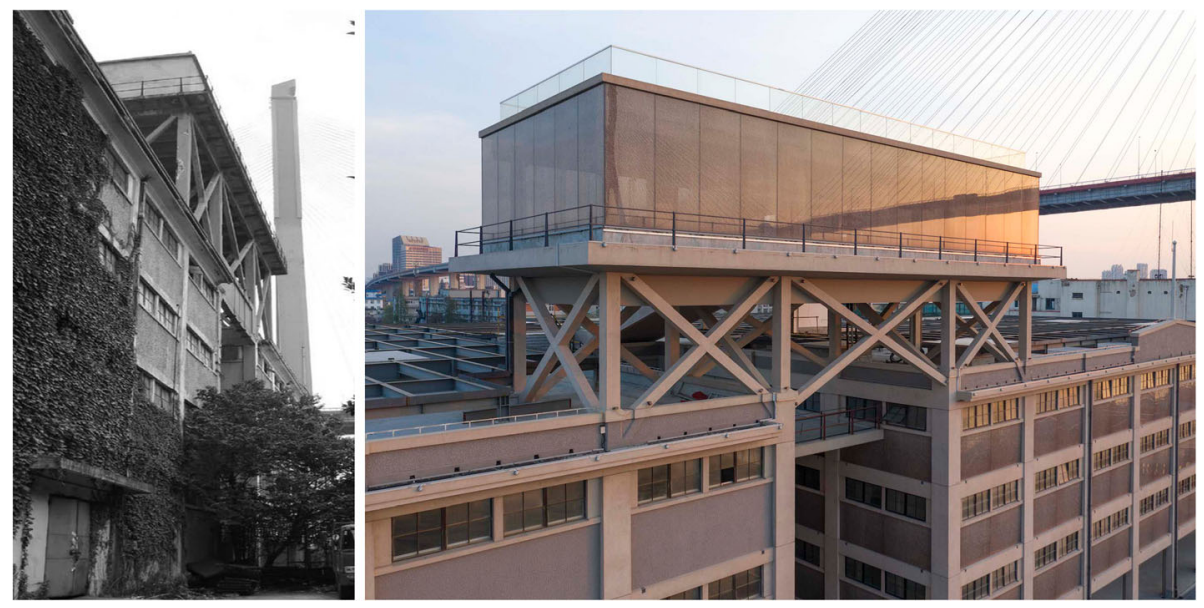

Fig. 15 Historical water tank vs. renovated observatory (Source: Fangfang Tian) 

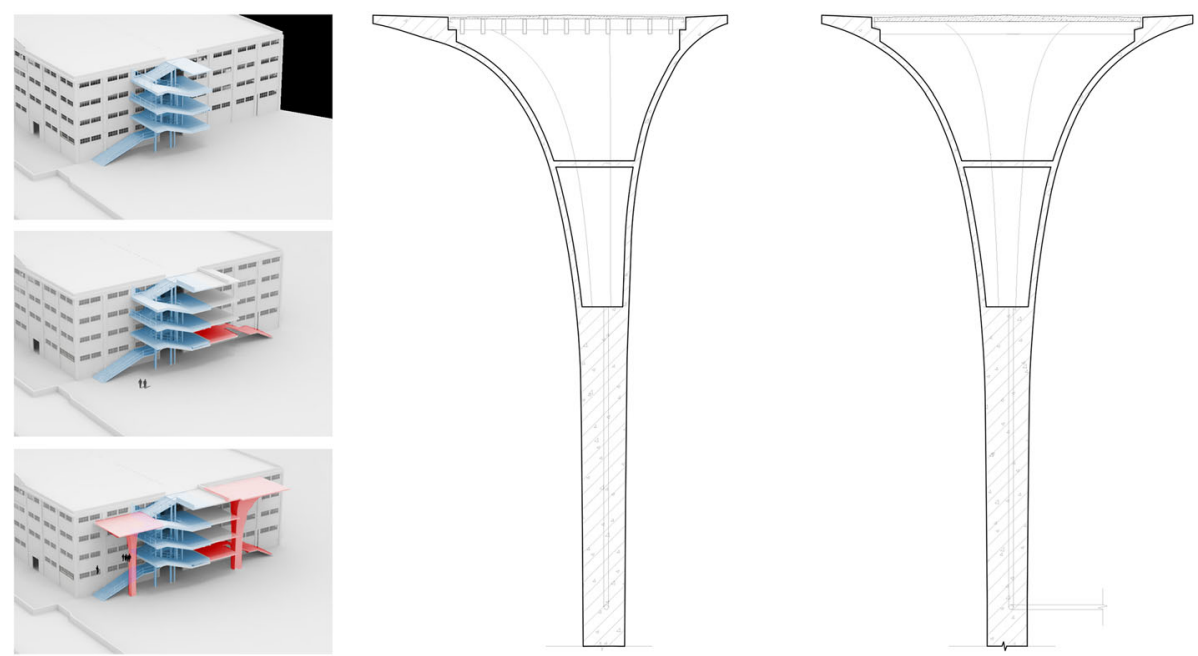

Fig. 16 Gigantic columns with built-in rainwater drainage system (Source: Archi-Union Architects)

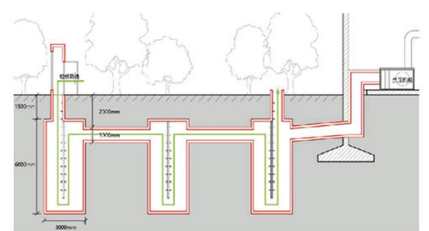

01 Ground-coupled heat exchanger

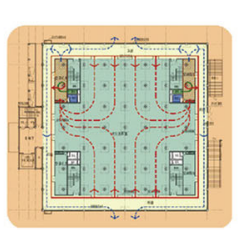

02 Thermal buffer space

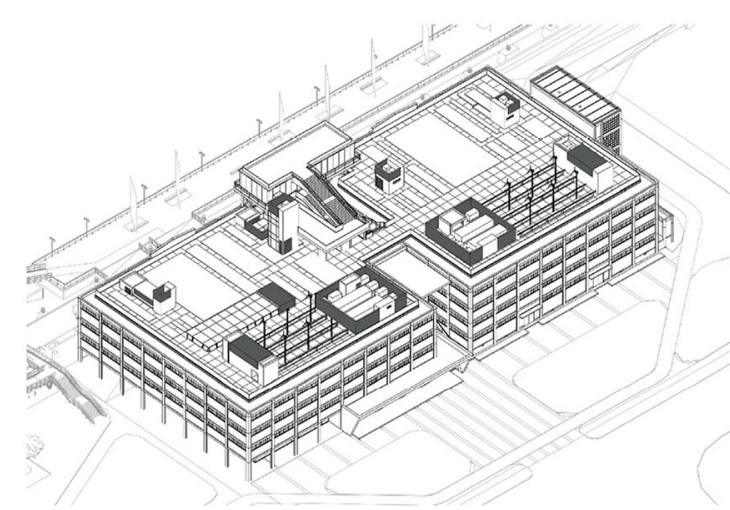

$05 \mathrm{BIM}$

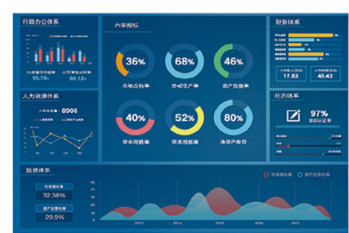

06 Energy monitoring \& visualization

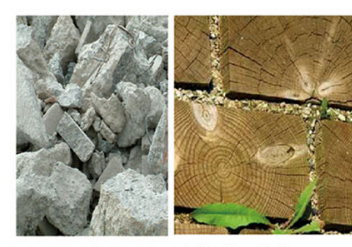

08 Sustainable building materials

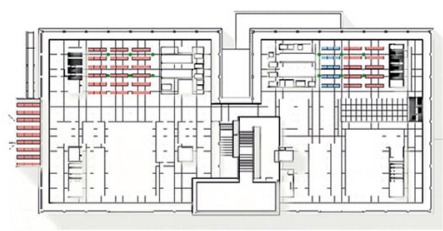

03 Wind and solar power

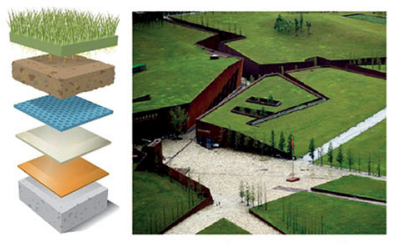

09 Green roof

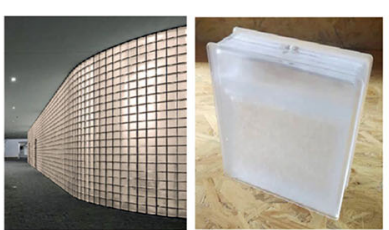

04 PCM wall

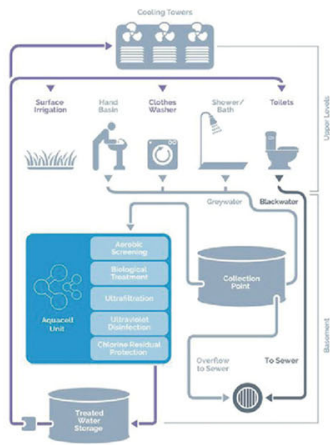

06 Rainwater harvesting

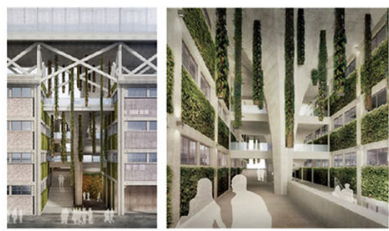

10 Vertical green

Fig. 17 Schematic proposal for the Yong'an Warehouse renovation (Source: 20a, 20b Archi-Union Architects) 

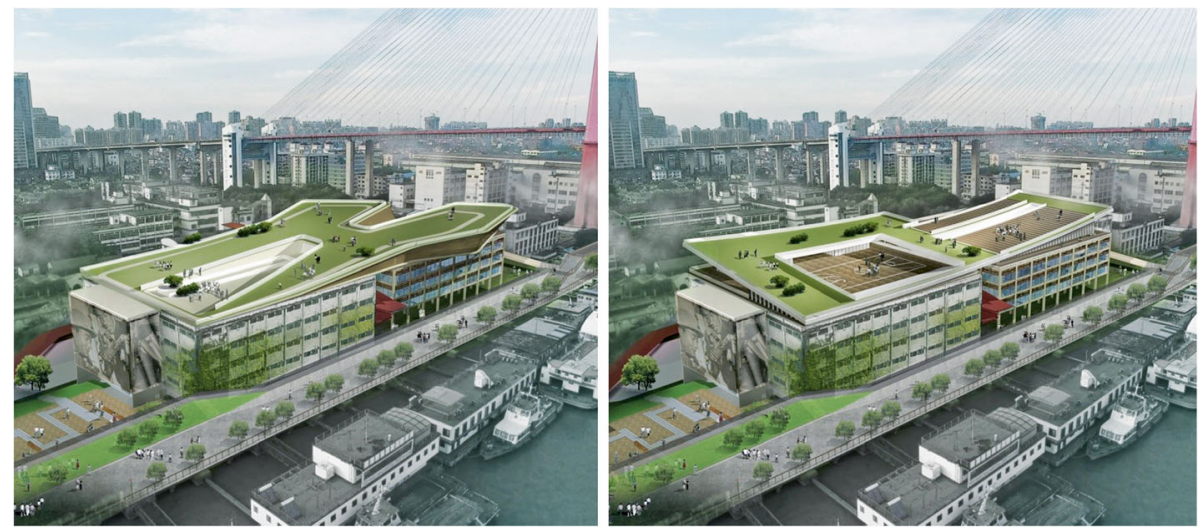

Fig. 18 Ten green ecological technologies used in the Yong'an Warehouse renovation (Source: Archi-Union Architects)

change material used in the new walls can also store heat using night-time electricity at lower costs to prepare for daytime consumption.

The original warehouse primarily used low-efficiency heating and electricity. Therefore, the design team installed wind and photovoltaic power generators and storage facilities on the rooftop to provide clean energy through complementary production between the two sources. The rooftop can also collect rainwater through the drainage system embedded in the gigantic columns. The rainwater eventually reaches a processing facility and is reused.

In addition, the architects utilised the atrium and open area to improve the ecological environment of the historic building. The combination of rooftop and vertical vegetation, as well as active light guiding and rainwater processing, ensure the closed internal recycling of the energy and water. There is a $1000 \mathrm{~m}^{2}$ area for vegetation on the roof. A ground-source ventilation system was also installed separate from the buildings in the adjacent open square to provide fresh air and thermal regulation through the exterior - underground - interior - rooftop - exterior underground piping and interior ventilation loop.

Further, the design team preserved most of the structural compartments as a foundation for future renovation and selected environmentally friendly materials with low energy costs. Implementation of Building Information Modelling (BIM) technology facilitated the design, construction and real-time monitoring of the environment, allowing visualisation of the energy cost via an integrated platform.

The technologies used in Yong'an Warehouse avoided direct intervention on the historic architecture and

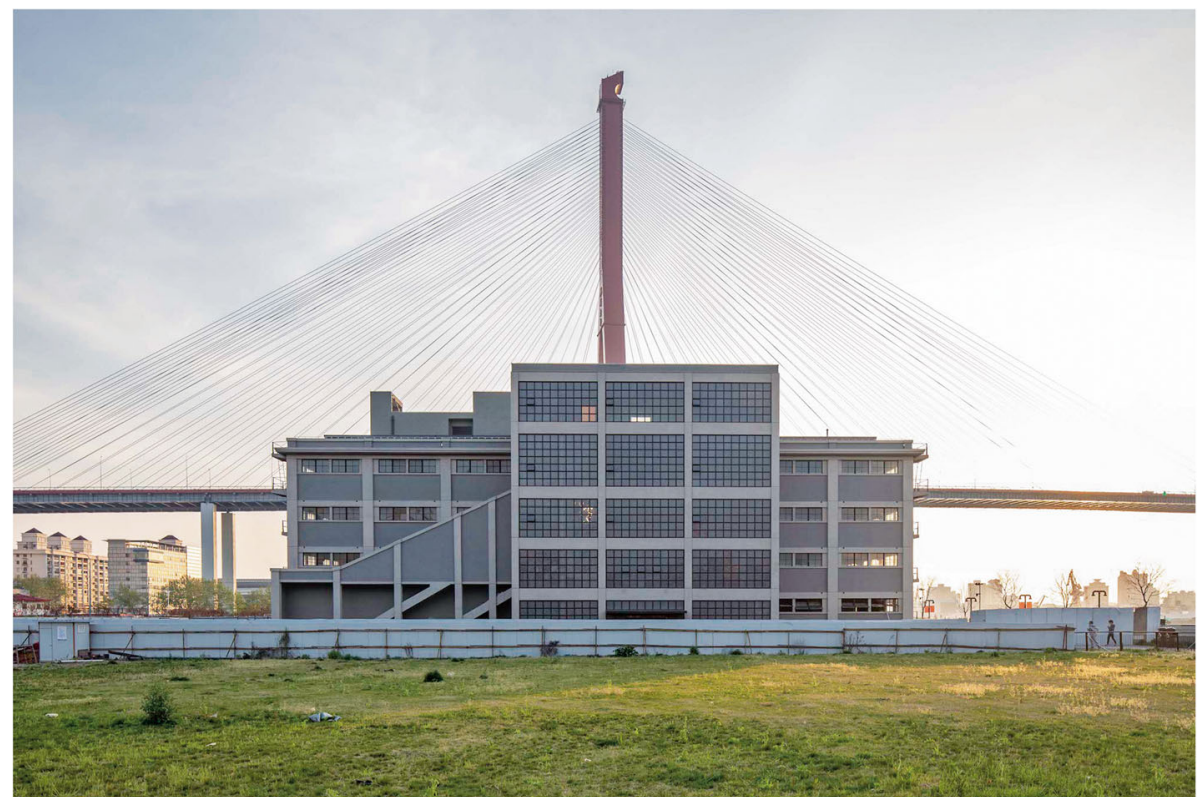

Fig. 19 West Elevation of the west wing after renovation (Source: Fangfang Tian) 
allowed the creation of coherence with the existing structures. Through the use of either removable or digital features, Yong'an Warehouse was able to meet the green building standards as an economical and sustainable piece of public architecture.

\section{Design process under multilateral involvement}

The economic environment, cultural background, and Archi-Union Architects' professional pursuits formed the key elements of the renovation strategies and decisions (Chang 2016). Since 2005, the protection of

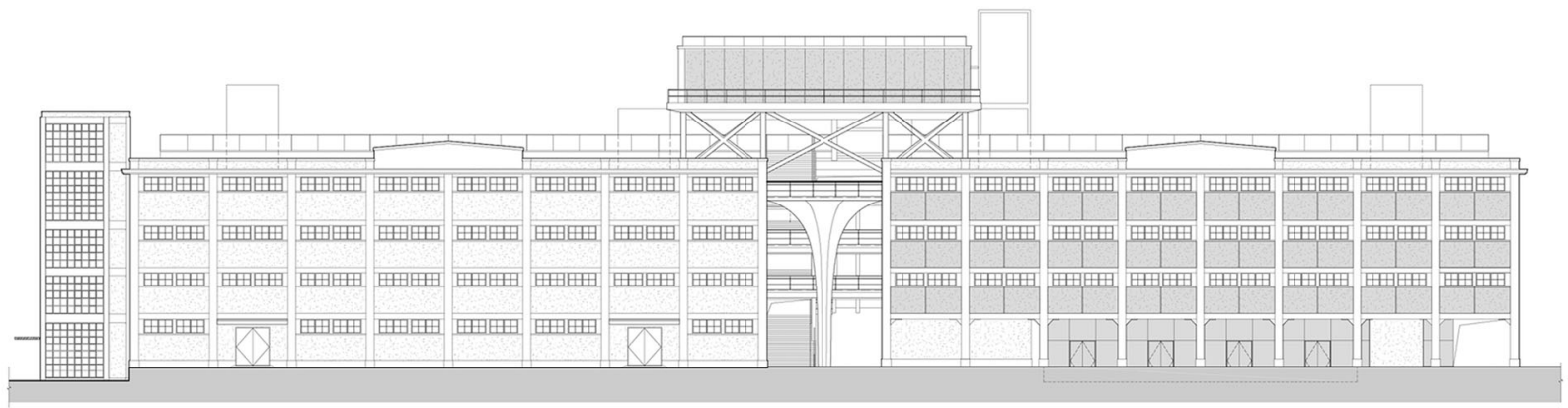

South Elevation

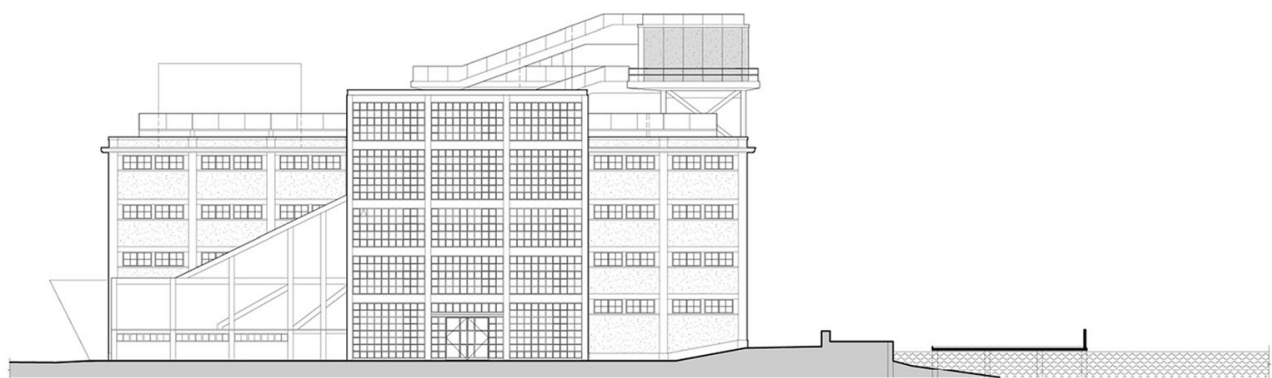

West Elevation
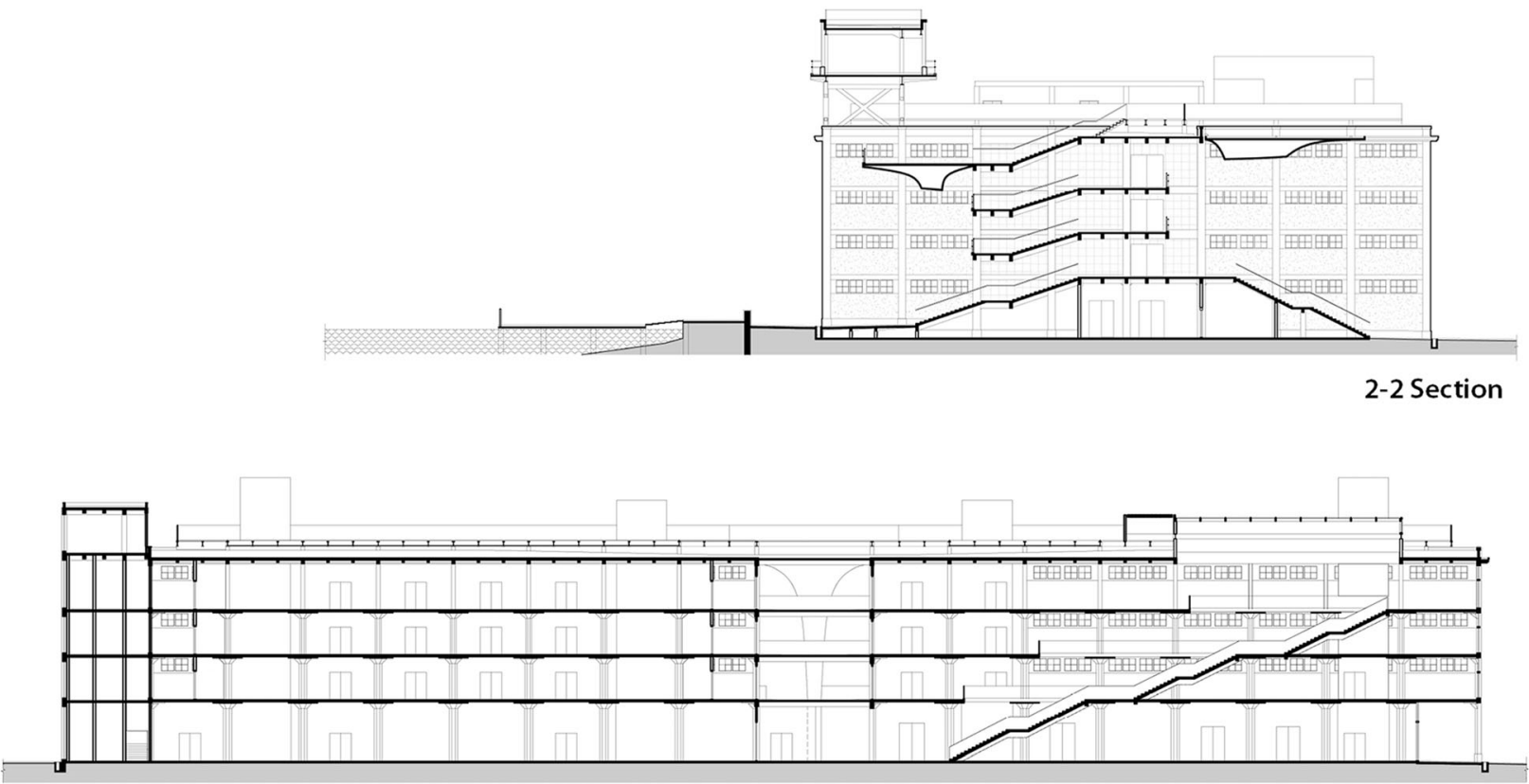

$\overline{05} \overline{10} 20$

1-1 Section

Fig. 20 Elevation and Section Drawings of the Yong'an Warehouse renovation (Source: Archi-Union Architects) 
heritages in Shanghai has been primarily a government effort to coordinate between different institutions. One of the renovation process's main objectives was multilateral communication among government officials, the owner, cultural heritage experts, construction experts, and construction contractors.

In this case, the warehouse's investor and owner wished to transform it into a green building to revitalise the ecology of the surroundings and provide infrastructure for new functions while staying in alignment with conservation requirements.

The overall strategy for cultural heritage must be approved by government officials and experts before implementation. The design proposal for Yong'an Warehouse went through several rounds of Q\&As and discussions with various departments and institutions. This created challenges for the design team as well as technical experts, as the local government proposed a much shorter time for proceeding with the Yangpu waterfront development.

The architects sought to expand the rooftop with additional structures to create a unique formal signature following the principles of conservation (Fig. 18). The board of experts acknowledged the renovation measures but preferred a more reserved approach with less intervention on the original structures. This would express the past and the future of the building's unique architecture in the spirit of historic preservation. After multiple rounds of revision and discussion, the architects refrained from bold changes to stay faithful to the historic appearance, which was approved by all the experts.

Most of the design concepts were realised in the construction, though a few remained unrealised. This was the result not only of the delicate balance between conservation and renovation but also of the uncertainty regarding institutional decision making throughout the design process.

\section{The progressive future of Yong'an Warehouse}

The renovation of Yong'an Warehouse resulted in a dynamic summation of the new and the old, the past and the future. On the premise of authenticity and legibility, the twin buildings approached a balanced relationship between historical value and contemporary functionality.

Built as an architectural highlight of the Yangpu waterfront, Yong'an Warehouse will continue to play a significant role in the urban development. Through this renovation, Yong'an Warehouse was reborn with its historical memories of the past and opportunities for the future (Figs. 19 and 20). Nevertheless, there were further design problems to be confronted for the warehouse to be integrated into the cityscape of Shanghai. Challenges such as effective loading capacity, structural integrity, height limits and functional flexibility create uncertainties for Yong'an Warehouse's future. Most importantly, with each shift in our understanding of the future, our perception of history changes. For historic architecture, the significance will be highly complex (Dutta 2015). How to integrate historic architecture into contemporary urban space will be a long-term debate as the definition of history continuously changes.

\section{Acknowledgements \\ All diagrams and drawings are credited to the author and Archi-Union Architects.}

\section{Authors' contributions}

Philip F. Yuan was the principal architect for the renovation project. Meanwhile, he was the major contributor who conducted the research, proposed the framework and helped with its implementation in the text and the analysis of the findings. Xiaoyu Wei drafted the manuscript, assisted with the research and analysis of the findings. Wei Yu undertook editing and proofreading the drafted contents. All authors read and approved the final manuscript.

\section{Funding}

This article is supported by the National Natural Science Foundation of China [Grant No U1913603].

Availability of data and materials

Not applicable.

\section{Declarations}

Competing interests

The author declare that they have no competing interests.

\section{Author details}

${ }^{1}$ College of Architecture and Urban Planning, Tongji University, 1239 Siping Road, Shanghai 200092, China. ${ }^{2}$ Tongji Architectural Design (Group)Co.,Ltd, 1230 Siping Road, Shanghai 200092, China. ${ }^{3}$ Archi-Union Architects, Building 36, 1436 Jungong Rd, Yangpu District, Shanghai 200433, China.

Received: 30 August 2020 Accepted: 28 April 2021

Published online: 31 May 2021

\section{References}

Chang, Qing. 2016. "Dui jianzhu yichan jiben wenti de renzhi." [Reflection on the fundamental category of heritage architecture]. Heritage Architecture 1: 44-61.

Chen, Xi, and Peng Zhang. 2018. "Women weishenme rengran Yao yuedu Ligeer-Guanyu goujian jianzhu yichan jiazhi de fansi." [Why we still need to read Alois Riegl? A reflection on constructing the value system of architecture heritage.]. Huazhong Architecture 12: 1-5.

Dutta, Arindam. 2015. "Weile weilai de huaijiu." [Nostalgia for the future]. Time + Architecture 5: 34-39.

ICOMOS. 1964. "International Charter for The Conservation and Restoration of Monuments and Sites (The Venice Charter 1964)." https://www.icomos.org/ charters/venice_e.pdf

Mason, Randall. 2016. "Lun yi jiazhi wei zhongxin de lishi baohu lilun yu Shijian." [Theoretical and practical arguments for values-centered preservation]. Heritage Architecture 3: 1-18.

Muñoz Viñas, Salvador. 2012. Dangdai baohu lilun [contemporary theory of conservation]. Translated and edited by Peng Zhang, Xinyi Zhang, and Xiaojing Wu. Shanghai: Tongji University Press.

Riegl, Alois. 1982. The modern cult of monuments: Its character and its origin. Oppositions Fall 25: 21-51.

Rong, Yueming. 2018. Shanghai Wenhua Fazhan Baogao (2018) [Shanghai cultural Development's annual report (2018)]. Shanghai: SHSD press.

\section{Publisher's Note}

Springer Nature remains neutral with regard to jurisdictional claims in published maps and institutional affiliations. 